\title{
The Association between Hypertension and Cognitive Function in Adolescents
}

\author{
Deasy Nediyanti ${ }^{1}$, Oke Rina Ramayani ${ }^{1}$, Munar Lubis ${ }^{1}$, Elmeida Effendy ${ }^{2}$, Rafita Ramayati ${ }^{1}$ and Rusdidjas ${ }^{1}$ \\ ${ }^{1}$ Departments of Child Health, University of Sumatera Utara, Medan, Indonesia \\ ${ }^{2}$ Psychiatry, University of Sumatera Utara, Medan, Indonesia
}

Submission: November 19, 2018; Published: December 03, 2018

*Corresponding author: Deasy Nediyanti, Department of Child Health, Medical School, University of Sumatera Utara/ H. Adam Malik Hospital, Jl. Bunga Lau No.17 Medan 20136, Indonesia

\begin{abstract}
Background: The prevalence of hypertension is increasing in childhood and usually asymptomatic but still has target organ damage manifestations. This condition may cause negative impacts on their cognitive function. Early detection and appropriate management on hypertension may lessen cognitive impairment associated with hypertension.

Methods: A cross sectional study was conducted among 193 children aged 12 to 17 years in Singkuang Village, Mandailing Natal Regency, North Sumatera on April 2016. Blood pressure and cognitive test scores were collected. Hypertension was defined as systolic or diastolic blood pressure at $\geq 95$ th percentile according to the Fourth report from the National High Blood Pressure Education Program Working Group on Children and Adolescent. Cognitive impairment was defined as borderline and lower cognitive test scores. Chi-square test was used to analyze the association between hypertension and cognitive function. The $\mathrm{P}$ value of $<0.05$ at $95 \%$ confidence interval (CI) was considered significant.
\end{abstract}

Results: Of 193 adolescents, 28\% had hypertension. Adolescentswith hypertension had lower Intelligence Quotient (IQ) scores compared with normotensive adolescents for verbal $(\mathrm{P}=0.008 ; \mathrm{PR}=2.381 ; \mathrm{CI}=1.244-4.559)$, performance $(\mathrm{P}=0.021 ; \mathrm{PR}=2.134 ; \mathrm{CI}=1.115-4.082)$, and fullscale domain ( $\mathrm{P}=0.005 ; \mathrm{PR}=2.475 ; \mathrm{CI}=1.295-4.730)$.

Conclusion: There is a significant association between hypertension and cognitive function in adolescents.

Keywords: Hypertension; Cognitive impairment; Adolescent

\section{Introduction}

The prevalence of hypertension in children tends to increase, but the possible neurologic effects are still neglected [1]. Primary hypertension are mostly found in school-age and adolescents, and its prevalence increases with an increased prevalence of obesity [2]. The global prevalence of hypertension in children is unknown globally, and oftenly this condition is undiagnosed. Age, height and obesity are risk factors for increased diagnosis and prevalence of hypertension in children [3]. Based on blood pressure measurement in three separate measurements, the prevalence of hypertension in children is about 1-3\% [4].The prevalence of hypertension and prehypertension in the age range 3-18 years are respectively 3.6\% and 3.4\%. The prevalence of hypertension and prehypertension in the age range 11 - 17 years are respectively $3.2 \%$ and $15.7 \%$ [5]. Other studies have shown the prevalence of abnormal blood pressure in adolescents aged 14-17 years is $11.5 \%$, with $2.5 \%$ of hypertension and $4 \%$ of persistent prehypertension. ${ }^{4}$ The presence of obesity is associated with an increased prevalence of hypertension and about $14 \%$ of prehypertension in adolescents developed into hypertension within 2 years [5].

Mild hypertension in children in young adults causes decreased performance in neuropsychologic test compared to control [6]. Children with chronic hypertension are at higher risk to have learning disturbances and executive function deficits, where cognitive impairments hits the prevalence number of $2.4 \%[1,7]$. The increasing blood pressure at $\geq 90^{\text {th }}$ percentile is associated with decreased mathematical ability in children aged 6 to 16 years compared to children with blood pressure at $<90^{\text {th }}$ percentile [8].

This cognitive impairment is possibly caused by disturbance of cerebral blood flow regulation. The increasing blood pressure in children also contributes in the increased risk of early atherosclerosis, which affects blood vessels in acute and chronic fashion.Studies regarding blood pressure in children are still lack in number and further studies to evaluate the clinical effect of hypertension on children's nervous system are mandatory $[1,9]$. 


\section{Methods}

\section{Study design and sample}

A cross-sectional study was conducted in Singkuang Village from April to May 2016. A total of 193samples were collected consecutively with the inclusion criteria: children aged 12 to 17 years, had blood pressure measured, and cognitive function tested. Hypertension was defined as systolic or diastolic blood pressure at $\geq 95^{\text {th }}$ percentile. Cognitive impairment was defined as borderline and lower cognitive test scores.

\section{Data Collection}

Baseline data were collected using questionnaire.Before filling the questionnaire, samples and their parents had explaination about the study. Informed consent was obtained from each sample's parent. Antrophometric measurement was done, including weight and height measurements. Blood pressure was measured three times in a resting and calm condition. Blood pressure was measured using mercury sphygmomanometer with appropriate cuff. A stethoscope was placed on brachial artery projection, proximal and medial to fossa cubiti and below the cuff to detect the Korotkoff sound. Blood pressure was measured at interval of 10 to 15 minutes and the mean value was calculated for systolic and diastolic blood pressure. The mean blood pressure was evaluated according to sex, age, and height, and projected in The Fourth Task Force table. All adolescents who fulfilled the inclusion criteria had cognitif test by psychologist from Psychology Faculty, Andalas University, Padang using WISC-IV (Weschler Intelligent Scale for Children) test which consisted of verbal, performance, and full scale components.

\section{Statistical Analysis}

Data were analyzed using computer software (SPSS version 19.0)to determine the association between hypertension and cognitive function, we used chi-square test and Fisher's exact test as the alternative.The $P$ value of $<0,05$ at $95 \%$ confidence interval was considered significant.

\section{Results}

A total of 193 children aged 12-17 years were used as samples, with mean values as follows : age of 14.0 years, body weight according to height of $102.09 \%$, body mass index of $18.6 \mathrm{~kg} / \mathrm{m}^{2}$. The samples consisted of 84 men and 109 women. Nutritional status consists of 2 malnutrition, 30 malnutrition, 115 good nutrition, 27 overweight and 19 obesity samples. There were 54 had hypertension and 139 children with normotency. The proportion of hypertension among junior high school students in Singkuang Village was $28 \%$. There were differences in body mass index and mother's occupation between hypertension and control group (P value 0.019 and 0.035 respectively). The difference in baseline characteristic between both group is shown in (Table 1).

Table 1: Baseline characteristic of sample.

\begin{tabular}{|c|c|c|}
\hline \multirow[t]{2}{*}{ Characteristic } & Hypertension & \multirow[t]{2}{*}{ Non-Hyertension $(<90$ th percentile) } \\
\hline & ( $\geq 90$ th percentile) & \\
\hline \multicolumn{3}{|l|}{ Gender, $\mathbf{n}$} \\
\hline Male & 18 & 66 \\
\hline Female & 36 & 73 \\
\hline Age (year), mean (SD) & $13.7(1.10)$ & $14.1(1.29)$ \\
\hline BW/ BH (\%), mean (SD) & $104.2(15.66)$ & $101.3(13.36)$ \\
\hline \multicolumn{3}{|l|}{ Nutritional status, $\mathbf{n}$} \\
\hline Severe malnutrition & 0 & 2 \\
\hline Mild malnutrition & 7 & 23 \\
\hline Normal & 32 & 83 \\
\hline Overweight & 9 & 18 \\
\hline Obese & 6 & 13 \\
\hline Body mass index $\left(\mathrm{kg} / \mathrm{m}^{2}\right)$, mean (SD) & $19.1(3.07)$ & $18.4(3.41)$ \\
\hline \multicolumn{3}{|l|}{ Father's education, $\mathrm{n}$} \\
\hline Elementary school & 42 & 88 \\
\hline Junior high school & 8 & 31 \\
\hline Senior high school & 4 & 19 \\
\hline Diploma & 0 & 1 \\
\hline
\end{tabular}




\section{JOJ Urology \& Nephrology}

\begin{tabular}{|c|c|c|}
\hline Mother's education, $\mathbf{n}$ & & \\
\hline Elementary school & 36 & 65 \\
\hline Junior high school & 15 & 42 \\
\hline Senior high school & 1 & 25 \\
\hline Diploma & 2 & 5 \\
\hline Bachelor & 0 & 2 \\
\hline \multicolumn{3}{|l|}{ Father's occupation } \\
\hline Government employer & 4 & 23 \\
\hline Private employer & 17 & 27 \\
\hline Enterpreneur & 7 & 22 \\
\hline Farmer/fisher & 22 & 53 \\
\hline Unemployed & 4 & 14 \\
\hline \multicolumn{3}{|l|}{ Mother's occupation } \\
\hline Government employer & 10 & 30 \\
\hline Private employer & 13 & 18 \\
\hline Enterpreneur & 3 & 18 \\
\hline Farmer/fisher & 18 & 62 \\
\hline Unemployed & 10 & 11 \\
\hline \multicolumn{3}{|l|}{ Father's income } \\
\hline$<500.000$ & 7 & 28 \\
\hline $500.000-1.000 .000$ & 26 & 60 \\
\hline $1.000 .000-3.000 .000$ & 21 & 51 \\
\hline \multicolumn{3}{|l|}{ Mother's income } \\
\hline$<500.000$ & 27 & 73 \\
\hline $500.000-1.000 .000$ & 20 & 48 \\
\hline $1.000 .000-3.000 .000$ & 7 & 18 \\
\hline
\end{tabular}

There was no decreased cognitive function based on sex $(\mathrm{P}=0.51)$, age $(\mathrm{P}=0.696)$, body weight for body height $(\mathrm{P}=0.512)$, nutritional status $(\mathrm{P}=0.273)$, father's education $(\mathrm{P}=0.883)$, mother's education $(\mathrm{P}=0.112)$, father's occupation $(\mathrm{P}=0.332)$, mother's occupation $(\mathrm{P}=0.059)$, Father's income $(\mathrm{P}=0.117)$, and

Table 2: Factors affecting cognitive function. mother's income $(\mathrm{P}=0.872)$. There was a relationship between body mass index and cognitive impairment $(\mathrm{P}=0.048)$, where samples with cognitive impairment had higher body mass index compared to samples with normal cognitive function. Factors affecting cognitive impairment were shown in (Table 2).

\begin{tabular}{|c|c|c|c|}
\hline Characteristic & Full scale cognitive impairment & No cognitive impairment & $\mathbf{p}$ \\
\hline \multicolumn{4}{|l|}{ Gender, $\mathbf{n}$} \\
\hline Male & 27 & 57 & 0.51 \\
\hline Female & 40 & 69 & \\
\hline Age (year), mean (SD) & $14.1(1.37)$ & $14.0(1.2)$ & 0.696 \\
\hline BW/ BH (\%), mean (SD) & $103.3(15.28)$ & $101.5(13.39)$ & 0.512 \\
\hline \multicolumn{4}{|l|}{ Nutritional Status, $\mathbf{n}$} \\
\hline Severe malnutrition & 0 & 2 & 0.273 \\
\hline Mild malnutrition & 7 & 23 & \\
\hline Normal & 45 & 70 & \\
\hline
\end{tabular}


JOJ Urology \& Nephrology

\begin{tabular}{|c|c|c|c|}
\hline Overweight & 7 & 20 & \\
\hline Obese & 8 & 11 & \\
\hline Body mass index $\left(\mathrm{kg} / \mathrm{m}^{2}\right)$, mean (SD) & $19.0(3.03)$ & $18.4(3.46)$ & 0.048 \\
\hline \multicolumn{4}{|l|}{ Father's Education, $\mathbf{n}$} \\
\hline Elementary school & 49 & 81 & 0.883 \\
\hline Junior high school & 12 & 27 & \\
\hline Senior high school & 6 & 17 & \\
\hline Diploma & 0 & 1 & \\
\hline \multicolumn{4}{|l|}{ Mother's Education, $n$} \\
\hline Elementary school & 34 & 58 & 0.112 \\
\hline Junior high school & 17 & 40 & \\
\hline Senior high school & 5 & 21 & \\
\hline Diploma & 2 & 5 & \\
\hline Bachelor & 0 & 2 & \\
\hline \multicolumn{4}{|l|}{ Father's Education } \\
\hline Government employer & 8 & 19 & 0.332 \\
\hline Private employer & 21 & 23 & \\
\hline Enterpreneur & 11 & 18 & \\
\hline Farmer/fisher & 23 & 52 & \\
\hline Unemployed & 4 & 14 & \\
\hline \multicolumn{4}{|l|}{ Mother's Education, $n$} \\
\hline Government employer & 14 & 26 & 0.059 \\
\hline Private employer & 15 & 16 & \\
\hline Enterpreneur & 3 & 18 & \\
\hline Farmer/fisher & 24 & 56 & \\
\hline Unemployed & 11 & 10 & \\
\hline \multicolumn{4}{|l|}{ Father's Income } \\
\hline$<500.000$ & 7 & 28 & 0.117 \\
\hline $500.000-1.000 .000$ & 34 & 52 & \\
\hline $1.000 .000-3.000 .000$ & 26 & 46 & \\
\hline \multicolumn{4}{|l|}{ Mother's Income } \\
\hline$<500.000$ & 33 & 67 & 0.872 \\
\hline $500.000-1.000 .000$ & 25 & 43 & \\
\hline $1.000 .000-3.000 .000$ & 9 & 16 & \\
\hline
\end{tabular}

There was an association between hypertension and verbal domain cognitive impairment $(\mathrm{P}=0.008)$. Of 65 samples having verbal domain cognitive impairment, 26 had hypertension and of 128 samples not having verbal domain cognitive impairment, 28 had hypertension.The association between hypertension and verbal domain cognitive impairment was shown in (Table 3). There was an association between hypertension and performance domain cognitive impairment $(\mathrm{P}=0.021)$. Of 65samples having performance domain cognitive impairment, 25 had hypertension and of 128 samples with normal cognitive function, 29 had hypertension. The association between hypertension and performance domain cognitive impairment was shown in (Table 4). 
Table 3. Association between hypertension and verbal domain cognitive impairment.

\begin{tabular}{|c|c|c|c|c|c|c|c|}
\hline & & & Verbal domain & & $\mathbf{P}$ & PR & CI $95 \%$ \\
\hline & & Impairment & Normal & Total & & & \\
\hline \multirow[t]{2}{*}{ Blood pressure } & Hypertension & 26 & 28 & 54 & 0.008 & 1.716 & $1.169-2.519$ \\
\hline & Non-hypertension & 39 & 100 & 139 & & & \\
\hline Total & & 65 & 128 & 193 & & & \\
\hline
\end{tabular}

Table 4: Association between hypertension and performance domain cognitive impairment.

\begin{tabular}{|c|c|c|c|c|c|c|c|}
\hline & & \multicolumn{3}{|c|}{ Performance domain } & \multirow[t]{2}{*}{$\mathbf{P}$} & \multirow[t]{2}{*}{ PR } & \multirow[t]{2}{*}{ CI $95 \%$} \\
\hline & & Impairment & Normal & Total & & & \\
\hline \multirow[t]{2}{*}{ Blood pressure } & Hypertension & 25 & 29 & 54 & 0.021 & 1.609 & $1.091-2.373$ \\
\hline & Non-hypertension & 40 & 99 & 139 & & & \\
\hline Total & & 65 & 128 & 193 & & & \\
\hline
\end{tabular}

There was an association between hypertension and full scale cognitive impairment $(\mathrm{P}=0.005)$. Of 67 samples having full scale cognitive impairment, 27 had hypertension and of 126 samples

not having full scale cognitive impairment, 29 had hypertension. The association between hypertension and full scale cognitive impairment was shown in (Table 5).

Table 5: Association between hypertension and full scale domain cognitive impairment.

\begin{tabular}{|c|c|c|c|c|c|c|c|}
\hline \multicolumn{2}{|c|}{} & \multicolumn{2}{|c|}{ Performance domain } & \multicolumn{2}{c|}{ P } & PR \\
\hline & Impairment & Normal & Total & & \\
\hline \multirow{2}{*}{ Blood pressure } & Hypertension & 25 & 29 & 54 & 0.021 & 1.609 & $1.091-2.373$ \\
\hline & Non-hypertension & 40 & 99 & 139 & & \\
\hline Total & & 65 & 128 & 193 & & & \\
\hline
\end{tabular}

\section{Discussion}

In this study, hypertension increased the incidence cognitive impairment by factor 1.5 , in verbal domain $(\mathrm{PR}=1.176$; $95 \%$ $\mathrm{CI}=1.169$ - 2.519), in performance domain ( $\mathrm{PR}=1.609 ; 95 \%$ $\mathrm{CI}=1.091$ - 2.373), and in full scale domain (PR=1.378; 95\% $\mathrm{CI}=1.196-2.524$ ). We used WICS-IV (Wechsler Intelligence Scale for Children-IV) test to evaluate cognitive function of samples.

The result of this study was confirmed by a study in United States in 1988 to 1994 by The National Health and Nutrition Examination Survey III. Children with systolic and diastolic blood pressure at $\geq 90^{\text {th }}$ percentile had lower mathematical ability compared to children with blood pressure at $<90^{\text {th }}$ percentile. ${ }^{8}$ The cognitive function was measured using Wechsler Intelligence Scale for Children, Revised (WISC-R) and Wide Range Achievement Test, Revised (WRAT-R). A study in United States in 2009 showed that children with hypertension and obesity had significantly higher executive disturbance compared to children with normal blood pressure, and children with hypertension had lower internalization and externalization score [10]. The measurement tools used in the study were Behavior Rating Inventory of Executive Function (BRIEF)form which was filled by parents, and Child Behavior Checklist (CBCL) to measure internalization and externalization ability. Another study from United States in 2009 reported that children with blood pressure at $\geq 90^{\text {th }}$ percentile had lower performance score of IQ WASI (92.4 vs 96.1; $\mathrm{P}=0.03$ ) andfull scale score of IQ WASI ( 93.4 vs 97.0; $\mathrm{P}=0.04$ ). Multivariate analysis showed that there was an association between low IQ score and 
increased blood pressure (increased blood pressure, $\beta=-3.7$, 95\% CI: -7.3 -(-0.06); systolic blood pressure, $\beta=-1,16,95 \% \mathrm{CI}$ : $-2,1-(-0,21)$; diastolic blood pressure, $\beta=-1,17,95 \%$ CI: $-1,8-(-$ ,055).The neurocognitive examinations consisted of: intelectual function measurement with Wechsler Abbreviated Scales of Intelligence (WASI); basic academic achievement with Wechsler Individual Achievement Test-II-Abreviated (WIAT-II-A); attention regulation with Conner's Continuous Performance Test-II (CPTII) and executive function level with Behavior Rating Inventory of Executive Function (Parent BRIEF) [11].

A study in United States in 2010 reported that children with primary hypertension had higher learning disturbance prevalence compared to children with normal blood pressure (OR:4.1; 95\% CI:1.8 - 9.4) [12].

The process of cognitive decline in hypertensive patients begins with pathological changes in the blood vessels of the brain, and as a result of this, the blood perfusion to the brain will be disrupted and will cause abnormalities in brain tissue, resulting in cerebral hypoperfusion that will cause decreased cognitive function. Damage that occurs in the decline in cognitive function due to hypertension risk factors are dependent with the areas of the cerebral disorders. Cognitive impairment that can occur are decreased attention (attention and concentration), memory and information storage disorders, language disorders such as sensory and motor sensory, visuospatial disorders, impaired executive function such as decreased calculation or ability to calculate, decision making and abstract thinking disorders [13,14].

This study shows that there is a difference in body mass index when compared with the incidence of hypertension, in which adolescents with hypertension have higher BMI than nonhypertension adolescents. Incidence of hypertension is increased in children with obesity, and previous studies have reported that obesity is a risk factor for hypertension (OR $=2.61$ ) $[1,3]$. Obesity and hypertension increase the incidence of impaired executive function in children [15].

This study showed that there was a difference in body mass index between both groups. Adolescents with hypertension had higher body mass index compared to adolescents with normal blood pressure. The incidence of hypertension was increased in obese population. Previous study stated that obesity was the risk factor for hypertension (OR=2.61) [1,3]. Both obesity and hypertension contributed to executive function disturbance [15]. The proportion of hypertension in this study was $28 \%$, which was higher than global proportion (15.7\%) [15]. Further evaluation regarding risk factors for hypertension is mandatory to grant adequate management. Hypertension in children and adolescents is associated with cognitive impairment and adult hypertension.
Proper management of hypertension will give significant improvement [11].

\section{Conclusion}

There is statistically significant association between hypertension and cognitive function in adolescents.

\section{References}

1. Sharma M, Kupferman JC, Brosgol Y, Paterno K, Goodman S, et al (2010) The effect of hypertension on the paediatric brain: a justifiable concern. Lancet Neurol 9(9): 933-940.

2. Lande MB (2016) Systemic Hypertension. In: Kliegman RM, Stanton BF, St. Geme II JW, Schor NF, Behrman RE (Eds.). Nelson textbook of pediatrics. (20 $0^{\text {th }}$ edn). Philadelphia. Elsevier Inc. 2294-2303.

3. Hansen ML, Gunn PW, Kaelber DC (2007) Underdiagnosis of hypertension in children and adolescent. JAMA 298(8): 874-879.

4. Falkner B (2010) Hypertension in children and adolescent: epidemiology and natural history. Pediatr Nephrol 25(7): 1219-1224.

5. Acosta AA, Samuels JA, Portman RJ, Redwine KM (2012) Prevalence of persistent prehypertension in adoloescents. J Pediatr 160(5): 757-761.

6. Lyngdoh T, Viswanathan B, Kobrosly R, van Wijngaarden E, Huber $\mathrm{B}$, et al. (2013) Blood pressure and cognitive function: a prospective analysis among adolescents in the Seychelles. J Hypertens 31(6): 11751182.

7. Kawatsu Y, Kaneko S, Karama M, Honda S (2012) Prevalence and risk factor of neurological impairment among children aged 6-9 years: from population based cross sectional study in western Kenya. BMC Pediatrics 12: 186.

8. Lande MB, Kaczorowski JM, Auinger P, Schwartz GJ, Weizmar M (2003) Elevated blood pressure and decreased cognitive function among school-age children and adolescent in the United States. J Pediatr 143(6): 720-724.

9. Thompson M, Dana T, Bougatsos C, Blazina I, Norris SL (2013) Screening for hypertension in children and adolescent to prevent cardiovascular disease. Pediatrics131(3): 490-525.

10. Wong LJ, Kupferman JC, Prohovnik I, Kirkham FJ, Goodman S, et al. (2011) Hypertension impairs vascular reactivity in the pediatric brain. Stroke 42(7): 1834-1838.

11. Lande MB, Adams H, Falkner B, Waldstein SR, Schwartz GJ, et al. (2010) Parental assessments of internalizing and externalizing behavior and executive function in children with primary hypertension after antihypertensive therapy. J Pediatr 157(1): 114-119.

12. Cullen B, O'neil B, Evans JJ, Coen RF, Lawlor BA (2007) A review of screening test for cognitive impairment. J Neurol Neurosurg Psychiatry 78(8): 790-799.

13. Arntzen KA, Schimer H, Wilsgaard T, Mathiesen EB (2011) Impact of Cardiovascular Risk Factors on Cognitive Function: The tromso study. European journal of Neurology 18(5): 737-743.

14. Kalra L, Birns J (2009) Cognitive Function and Hypertension. J Hum Hypertens 23(2): 86-96.

15. Ingelfinger JR (2008) Etiology of children hypertension. In: Geary DF, Schaefer F (Eds.). Comprehensive pediatric nephrology. Mosby Elsevier, Philadelphia, USA, pp. 665-675. 
(C) This work is licensed under Creative (C) (1) Commons Attribution 4.0 License BY DOI: 10.19080/JOJUN.2018.06.555683
Your next submission with Juniper Publishers will reach you the below assets

- Quality Editorial service

- Swift Peer Review

- Reprints availability

- E-prints Service

- Manuscript Podcast for convenient understanding

- Global attainment for your research

- Manuscript accessibility in different formats

( Pdf, E-pub, Full Text, Audio)

- Unceasing customer service

Track the below URL for one-step submission https://juniperpublishers.com/online-submission.php 